\title{
EVALUATION OF SOME BUSINESS MACRO ENVIRONMENT FORECASTING METHODS
}

\author{
Vulfs Kozlinskis ${ }^{1}$, Kristine Guseva ${ }^{2}$ \\ Riga International School of Economics and Business Administration (RISEBA), \\ Meza iela 1, k. 2, LV-1048 Riga, Latvia \\ E-mail: ${ }^{1}$ Vulfs@ rsebaa.lv, ${ }^{2}$ kris@ rsebaa.lv
}

Received 0603 2006; accepted 28042006

\begin{abstract}
Latest studies in the field of business macro environment (BME) assessment and forecasting have been undertaken and successfully implemented by the World Bank (2003-2004). Considerable contribution to the field has been made by Nobel Prize winners in Economics F. Kydland and E. Prescott in 2004. Nonetheless, a number of issues concerning BME evaluation and forecasting is still left unstudied.

The Article highlights two major issues of BME: the fist part of the paper is focused on assessment of BME and the quality of BME development prognosis made by entrepreneurs. Based on key findings the following second part of the research examines the accuracy (validity) of businessmen prognosis and identifies key indicators businessmen rely on for formulating their future expectations. For that purpose a system of parameters and trends, as well as entrepreneurs' survey results have been applied.

The study concludes by illustrating the effect of inaccurately formulated prognosis and expectation on further development of BME events in conjunction with new assessment and forecasting proposals.
\end{abstract}

Keywords: business macro environment, assessment, forecasting, expectations.

\section{Introduction}

Business and consumer surveys as separate tools are widely used for short-term economic analysis. They have become an indispensable tool for economic surveillance in the EU and for monitoring the evolution of the European Monetary Union as well as the development of the future Member States' economies.

In the context of economic globalization, countries are increasingly concerned with the conduciveness of their business environment to private investment and business development, the priorities for reform, and their relative standing in their region or globally. Unfortunately, there are very few indicators that allow objectively measuring and comparing the business environment, its binding constraints, the quality of supportive and regulatory public services, and their relative improvement or decline over time.

A serious care of BME evaluation issue has been taken by developing countries, for instance EU new member-countries, aspiring to become equivalent partners in the world economy.

Our previous studies carried out from 2000 through 2005 revealed that taken alone BME evaluation methods do not provide with accurate data. Therefore, for a more in-depth and reliable evaluation and forecasting of BME a combination method incorporating business surveys and aggregate indicator trend should be applied.

\section{The importance of BME monitoring}

Significance and need for BME assessment and forecasting is based on:

- The growing role of government in support of successful and productive economic activity that strengthens the role of information in decision-making for policymakers (Finn E. Kydland and Edward C. Prescott, Nobel Prize in Economics 2004).

- Business community as the one that meaningfully contributes to the building blocks 
of successful economic development and improved competitiveness calls for reliable information on identification of critical factors in the development process.

- Attractiveness for foreign investors as a key factor for the development and serves as a signal for a decision.

\section{Evolution of BME monitoring}

Traditional assessment of the BME is based on the analysis of statistical data system. A considerable recent contribution to the business environment issue has been brought by work of World Bank, World Economic Forum, Michael Porter and others [1, 2].

There is an increasing interest in the use of surveys for predicting turning points in the economic cycle.

The business surveys have become an indispensable tool for short term economic analysis, surveillance and for monitoring the development of the economies.

\section{The Research}

Present paper is a logical continuation of the previous researches undertaken by Janis un Aija Vucani with Vulfs Kozlinskis on BME evaluation and comparative analysis. We have studied the possibilities of BME evaluation and forecasting via use of integrated indicator.

Key tasks of the paper are:

- To assess the quality of BME development prognosis made by the business community;

- To identify the basis - key indicatorsbusinessmen rely on for formulation of their future; expectations of BME development;

- To formulate directions of further research.

\section{Research Methodology}

The study was designed to gauge the quality and validity of entrepreneurs' expectations and prognosis of BME development in order to get insight into to the likely trends in the basics of businessmen decision-making.

For the purpose of such investigation information can be obtained at least in two ways:

- from special opinion polls of entrepreneurs,

- from official statistical data (indicators) that characterizes the business environment.
The authors believe that an accurate assessment of the BME requires carefully selected and complexly processed information from these two sources.

Following that the present research was constructed using the mentioned secondary data, i.e. official statistical data and entrepreneur opinion surveys. The countries represented in the study are Latvia and Germany.

The methods used:

- Graphical;

- Correlation analysis;

- Abstractly - logical analysis.

\section{Research limitations}

The main methodological problem encountered within the implementation of the study in Latvia was the lack of relevant and appropriate opinion polls of entrepreneurs in the previous years.

Due to this shortcut in data availability in Latvia, Germany has been selected to test the research hypothesis. Additional reason: Germany-homeland of Ifo, has a more distributed business environment index.

N. Viner stated an idea about short period of observations in socio-economical systems in general. Nowadays there does not exist data about enough long homogenous period of observation. The speed of changes is so quick that qualitative differences between the decades have become crucial.

\section{Results and discussions}

\section{Selected worldwide indexes for economic climate or BME}

Economically developed countries have gone much ahead and practice BME evaluation and forecasting of business environment on a regular basis since 1950s.

Information Research Institute, Germany (Ifo Institute) is a good methodological example of evaluation and forecasting of BME by using opinion polls of entrepreneurs [3]. This institute regularly calculates the socalled Ifo Business Climate Index, separately for West and East Germany. Practiced since 1991 Ifo index is a widely recognized and observed indicator for the economic development in Germany.

In recent years significant contribution to the issue of BME assessment has been undertaken by the World 
Bank. In 1999 and 2002 the World Bank in joint with European Bank for Reconstruction and Development (EBRD) undertook a Business Environment and Enterprise Performance Survey. Later on, in 2003 another survey World Business Environment Survey, administered to enterprises in 80 countries and one territory, has been launched.

These studies are targeted at managers, owners of companies around the world, designed to generate comparative measurements of the investment climate and the business environment that allow comparison across countries and over time.

Another influential annual study executed by World Economic Forum is Global Competitiveness Index, which to date is one of the leading monitors of the competitive condition of economies worldwide. The investigation is carried out in collaboration with 109 partner Institutes and is based on official statistical data with Executive survey data in over 100 economies (Table 1).

Table 1. International business climate surveys

\begin{tabular}{|c|c|c|c|c|c|c|}
\hline The survey & $\begin{array}{l}\text { Target } \\
\text { country }\end{array}$ & $\begin{array}{c}\text { Starting } \\
\text { date }\end{array}$ & Respondents & $\begin{array}{l}\text { Time scale } \\
\text { for } \\
\text { prognosis }\end{array}$ & Implemented & Methodology \\
\hline $\begin{array}{l}\text { Ifo Business } \\
\text { Climate } \\
\text { Index Ifo } \\
\text { Institute }\end{array}$ & $\begin{array}{l}\text { Germany, } \\
\text { worldwide }\end{array}$ & 1991 & $\begin{array}{c}7000 \\
\text { enterprises }\end{array}$ & 6 months & monthly & $\begin{array}{l}\text { Basis: opinion polls. Assesses } \\
\text { entrepreneurs' perceptions of } \\
\text { the business situation and } \\
\text { their expectations for the next } \\
\text { six months in manufacturing, } \\
\text { construction, wholesaling, and } \\
\text { retailing. }\end{array}$ \\
\hline $\begin{array}{l}\text { CESIfo } \\
\text { World } \\
\text { Economic } \\
\text { Survey } \\
\text { Ifo Institute }\end{array}$ & Worldwide & & $\begin{array}{c}1118 \\
\text { economic } \\
\text { experts, } 91 \\
\text { country }\end{array}$ & 3 months & quarterly & $\begin{array}{l}\text { Basis: opinion polls. Assesses } \\
\text { entrepreneurs' perceptions of } \\
\text { the country's general } \\
\text { economic situation and } \\
\text { expectations regarding } \\
\text { important economic } \\
\text { indicators. }\end{array}$ \\
\hline $\begin{array}{l}\text { Global } \\
\text { Competitive- } \\
\text { ness Index } \\
\text { World } \\
\text { Economic } \\
\text { Forum }\end{array}$ & $\begin{array}{l}\text { More than } \\
100 \\
\text { countries } \\
\text { worldwide }\end{array}$ & 1979 & $\begin{array}{l}7500 \\
\text { business } \\
\text { leaders, } \\
\text { entre- } \\
\text { preneurs }\end{array}$ & 1 year & annually & $\begin{array}{l}\text { Basis: Executive opinion polls } \\
\text { and hard data. Assesses the } \\
\text { importance of broad range of } \\
\text { factors central to creating a } \\
\text { healthy business environment } \\
\text { in support of successful and } \\
\text { productive economic activity. }\end{array}$ \\
\hline \begin{tabular}{l|} 
World \\
Business \\
Environment \\
Survey \\
The World \\
Bank \\
Institute
\end{tabular} & $\begin{array}{l}80 \text { countries } \\
\text { worldwide }\end{array}$ & $\begin{array}{l}1999 / \\
2000\end{array}$ & $\begin{array}{c}10090 \\
\text { businesses }\end{array}$ & $\mathrm{n} / \mathrm{a}$ & once & $\begin{array}{l}\text { Basis: opinion polls, } \\
\text { interviews. Measures } \\
\text { entrepreneurs' perceptions of } \\
\text { constraints or problems } \\
\text { impacting on their operations } \\
\text { in a particular country. }\end{array}$ \\
\hline $\begin{array}{l}\text { Business } \\
\text { environment } \\
\text { and } \\
\text { enterprise } \\
\text { performance } \\
\text { survey } \\
\text { World Bank, } \\
\text { EBRD }\end{array}$ & $\begin{array}{c}28 \\
\text { transitional } \\
\text { economies }\end{array}$ & 1999 & $\begin{array}{c}6500 \\
\text { enterprises }\end{array}$ & $\mathrm{n} / \mathrm{a}$ & 2 times & $\begin{array}{l}\text { Basis: opinion polls. These } \\
\text { qualitative measures are } \\
\text { compared with both objective } \\
\text { statistical measures, where } \\
\text { possible, and quantitative } \\
\text { business environment } \\
\text { measures. Generates } \\
\text { comparative measurements on } \\
\text { various business environment } \\
\text { dimensions. }\end{array}$ \\
\hline
\end{tabular}


The analysis of these studies reveals:

- Common purpose: to measure and prognose BME to achieve comparability of economies.

- Target territory: worldwide

- Prevailing methodology: opinion surveys.

- Implemented: mostly regularly.

\section{Selected Latvian Indexes for Economic Climate or BME}

Observing BME evaluation practices in Baltic's region it is significant to note that they started on the verge of $21^{\text {st }}$ century - the period before accession into EU when the comparative analysis of BME development in new and existing EU countries has become crucial for further success of the Union enlargement and development. The first attempt was made by all three countries' Statistical \& Research Institutes in coo- peration with Central Statistical Bureaus following the recommendations of the EU governing bodies. As a consequence Economic Sentiment Index has been developed with the aim to evaluate the socioeconomical condition of the country on the basis of business and consumer survey results. The methodology applied is based on Eurostat practices.

Further, in March 2004, one of the largest banks in Latvia - Parex Bank has launched its own BME survey called Parex Business Activity Index [4, 5]. The index is targeted to measure changes of entrepreneurs' perceptions and future expectations of the economic situation in Latvia as a whole and in separate industries.

Key observations:

- Common purpose: assessment and forecasting of business environment.

Table 2. Business climate evaluation in Baltic countries

\begin{tabular}{|c|c|c|c|c|c|c|}
\hline \multicolumn{7}{|c|}{ Surveys in Baltic countries } \\
\hline & $\begin{array}{l}\text { Target } \\
\text { country }\end{array}$ & $\begin{array}{l}\text { Starting } \\
\text { date }\end{array}$ & Respondents & $\begin{array}{l}\text { Time scale } \\
\text { for } \\
\text { prognosis }\end{array}$ & Implemented & Methodology \\
\hline $\begin{array}{l}\text { Set of statistical } \\
\text { indicators }\end{array}$ & Latvia & $1990 \mathrm{~s}$ & - & $\begin{array}{l}6 \text { months - } \\
5 \text { years }\end{array}$ & episodically & $\begin{array}{l}\text { Basis: there does not exist a } \\
\text { methodology as such. It is a } \\
\text { set of different indicators } \\
\text { used by different authors. }\end{array}$ \\
\hline $\begin{array}{l}\text { Economic } \\
\text { Sentiment Index } \\
\text { Latvia Statistical } \\
\text { Institute }\end{array}$ & $\begin{array}{c}\text { Baltic } \\
\text { countries }\end{array}$ & $\begin{array}{l}1992 \\
2001\end{array}$ & $\mathrm{n} / \mathrm{a}$ & 1 month & monthly & $\begin{array}{l}\text { EUROSTAT methodology. } \\
\text { Basis: opinion polls. Assesses } \\
\text { entrepreneurs' perceptions of } \\
\text { the current and future } \\
\text { business situation for } \\
\text { comparative analysis. }\end{array}$ \\
\hline $\begin{array}{l}\text { PAREX Business } \\
\text { Activity Index } \\
\text { SKDS market \& } \\
\text { public opinion } \\
\text { research centre }\end{array}$ & Latvia & 2004 & $\begin{array}{c}750 \\
\text { enterprises }\end{array}$ & 6 months & quarterly & $\begin{array}{l}\text { Basis: opinion polls by phone } \\
\text { interviews. Measures } \\
\text { entrepreneurs' assessment of } \\
\text { business environment in } \\
\text { present in comparison with } \\
\text { last } 6 \text { months and future } \\
\text { expectations ( } 6 \text { months). }\end{array}$ \\
\hline $\begin{array}{l}\text { VUKO Index } \\
\text { Ventspils } \\
\text { University College, } \\
\text { RISEBA }\end{array}$ & $\begin{array}{l}\text { Latvia, } \\
\text { partially } \\
\text { Baltic's }\end{array}$ & 2001 & - & 1-2 years & episodically & $\begin{array}{l}\text { Basis: statistical data. } \\
\text { Measures business } \\
\text { environment and is } \\
\text { applicable for forecasting. } \\
\text { First step: calculation of } \\
\text { integrated index on BME } \\
\text { components. Second step: } \\
\text { calculation of integrated }\end{array}$ \\
\hline
\end{tabular}




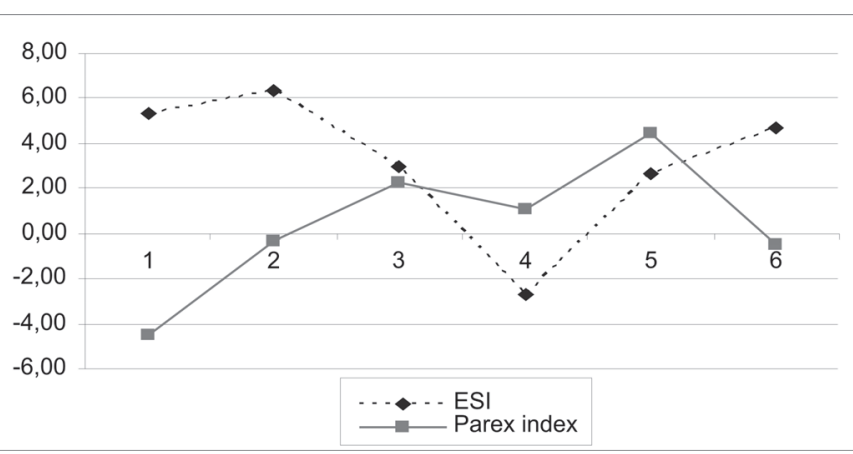

Fig 1. ESI vs Parex Index, 2004-2005

- Prevailing methodology: opinion surveys.

- Drawback: short observation period.

- The system of BME evaluation is young in Latvia and yet developing.

\section{Comparison of selected Latvian Indexes}

Economic Sentiment Index versus Parex Business Activity Index (Fig 1).

Since the observation period taken for comparison of two indexes is 6 quarters, the applicability of the given information is limited (prognosis differ) to identification of the overall signal rather than market trend.

\section{Key conclusions:}

- Drawback: short observation period. Further research is necessary.

- Both indexes conflict.

- The opinion survey method of BME development forecasting is approximate.

Opportunities and possibilities for application of BME forecasting on the basis of entrepreneurs' opinion surveys are limited. It is not clear what is the basis business community relies on in making future forecasts.

Research Question 1: evaluate the quality of BME development prognosis made by the business community

- Investigation of the given issue is based on entrepreneurs' opinion surveys and hard data.

- To measure the quality of businessmen prognosis of BME changes the following opinion surveys were selected:

LATVIA: economic sentiment index

GERMANY: Ifo business expectations index

For more detailed forecasting of BME in the past and also to make its future forecasts in the situation of insufficient direct information, obtained from entrepreneurs, it is advisable to use the analysis of official statistical data.

Key indicators that have been used for the analysis in the present investigation (the choice of indicators is based on previous research studies made by Vucans' family and V.Kozlinskis): GDP per capita, rate of unemployed, price index, short-term and long-term interest rates.

\section{Major findings in Latvia}

The study implemented to identify the interrelation between ESI and GDP, rate of unemployed, price index, short and long-term interest rates shows that practically there is no relation between the real changes of indicators and the prognosis (ESI in Latvia) (Fig 2, 3).

More clear connection between Ifo index and indicators is shown by correlation coefficients (Fig 4).

In general, it looks like Ifo is a little bit more precise than the Economic Sentiment Index in Latvia (correlation: Ifo vs GDP $=|0,59|$ ).

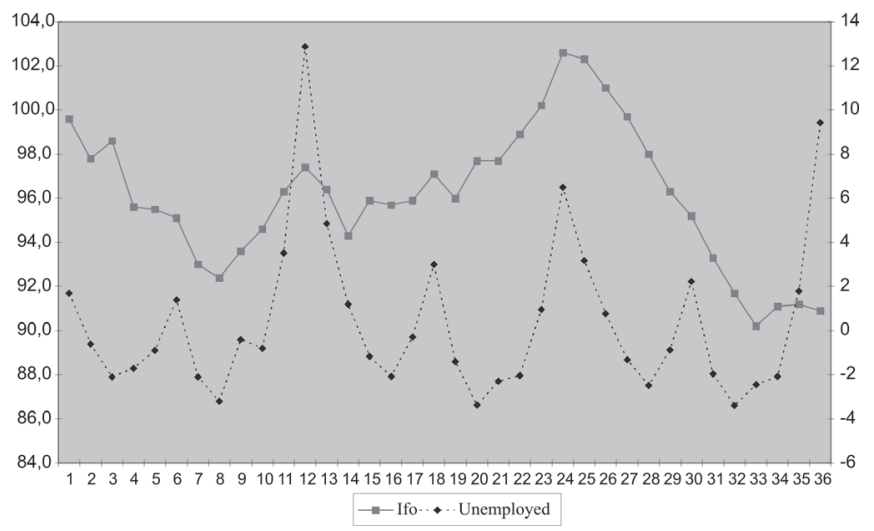

Fig 2. Ifo vs Rate of unemployed, 2002-2005

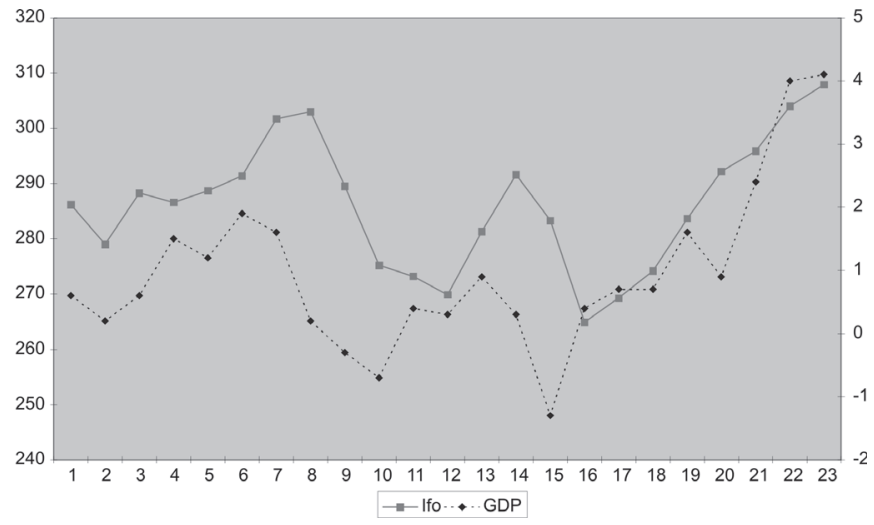

Fig 3. Ifo vs GDP, 2002-2005 


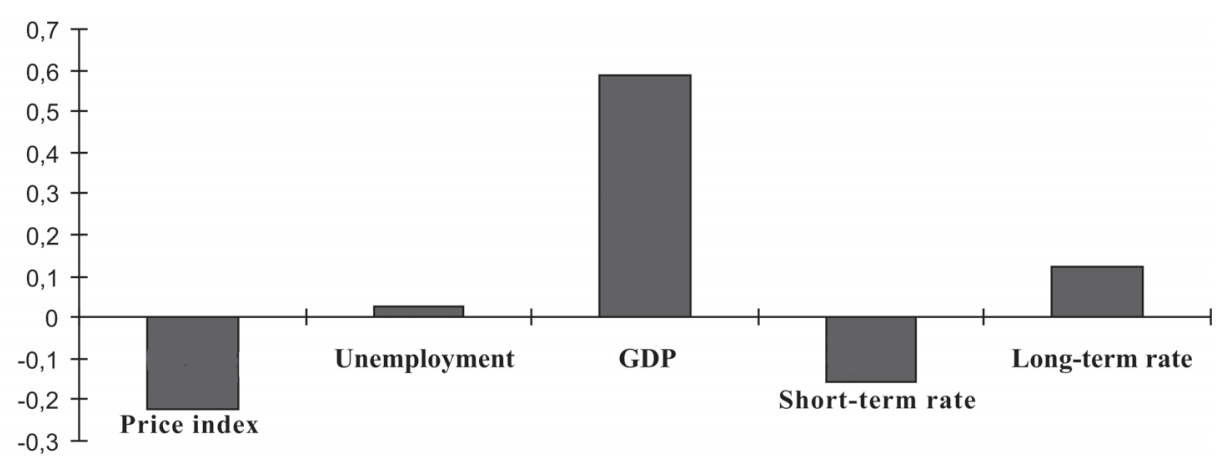

Fig 4. Correlation coefficients: Ifo vs Indicators, 2002-2005

Table 3. Correlation coefficients in Latvia (2003-2005)

\begin{tabular}{|c|c|c|c|c|c|}
\hline & GDP & Price Index & $\begin{array}{c}\text { Rate of } \\
\text { unemployed }\end{array}$ & $\begin{array}{c}\text { Short-term } \\
\text { interest rate }\end{array}$ & $\begin{array}{c}\text { Long-term } \\
\text { interest rate }\end{array}$ \\
\hline $\begin{array}{c}\text { Economic } \\
\text { Sentiment Index }\end{array}$ & 0,4895 & 0,7132 & $-0,5793$ & $-0,0787$ & $-0,1568$ \\
\hline
\end{tabular}

Table 4. Correlation coefficients in Germany (2002-2005)

\begin{tabular}{|c|c|c|c|c|c|}
\hline & GDP & Price Index & $\begin{array}{c}\text { Rate of } \\
\text { unemployed }\end{array}$ & $\begin{array}{c}\text { Short-term } \\
\text { interest rate }\end{array}$ & $\begin{array}{c}\text { Long-term } \\
\text { interest rate }\end{array}$ \\
\hline Ifo & $-0,5945$ & $-0,0829$ & 0,1200 & $-0,1582$ & 0,1226 \\
\hline
\end{tabular}

Research Question 2: identify key indicators businessmen rely on for formulation of their future expectations of BME development.

\section{Key observations:}

For Latvia:

- Correlation between the prognosis and selected statistical indicators has not been observed. Exception: price index (correlation between ESI and price index is 0,7132) (Table 3).

- Presumably, in Latvia business community generally tends to rely on events within their enterprises, except for the price index, because the speed of its growth in Latvia in recent years has been high. Price index level in 2004 was 114.2 and in $2005-121.9(2000=100)$ [6].

- ESI is very fluctuating in Latvia thus puts under question the validity of the basis for forecasting.

For Germany:

- Correlation is observed in case of GDP (Table 4).

- Assumption: German entrepreneurs when making prognosis take into account at least one macroeconomic indicator - GDP [7].
At the given stage of the research it is clear that the assessment of the BME on the basis of the entrepreneurs' opinion surveys represents a so-called "black box" when the inflowing information is unknown and out-flowing information is very approximate.

\section{Conclusions and suggestions}

- The connection between expectations hold by the business community about the BME changes and what has followed in fact is very weak.

- Entrepreneurs' prognosis in Germany is based on the change of GDP, while in Latvia it presumably is limited to the condition of own business (however, further testing on the issue is necessary). In Latvia only recently we can observe some correlation between prognosis (ESI) and price index.

- Preliminary results reveal that in formulation of future prognosis entrepreneurs focus only on some widely used statistical indicators but those of the previous period (possible to speak about the lag of information influence), as in the case of Latvia and Germany.

- Therefore, based on previous researches and 
the present study the best evaluation and forecasting approach on BME development is to use an integrated indicator complemented by the qualitative opinion surveys of the business community.

\section{Recommendations for further research}

1. To implement repetitive research based on extended time framework.

2. For the case of Latvia: calculate the correlation of ESI and integrated indicator.

\section{References}

1. Global competitiveness report. World economic forum. Home page: www.weforum.org

2. The Bank of Sweden Prize in Economic Sciences in Memory of Alfred Nobel 2004. Home page: www.nobelprize.org

3. Center for Economic Studies, The Ifo Institute for Economic research. Home page: www.cesifo.de

4. Parex Business activity index. Home page: http:// www.parex.lv/lv/index/

5. Economic Sentiment Index. Latvian Institute of Statistics, quarterly editions.

6. Central Statistical Bureau of Latvia. Home page: www.csb.lv

7. Federal Statistical Office of Germany. Home page: www.destatis.de 